\title{
What motivates 'free' revealing? Measuring outbound non-pecuniary openness, innovation types and expectations of future profit growth
}

\author{
Martie-Louise Verreynne ${ }^{1} \cdot$ Rui Torres de Oliveira ${ }^{2} \cdot$ John Steen $^{3} \cdot$ Marta Indulska $^{4}$. \\ Jerad A. Ford ${ }^{5}$
}

Received: 9 September 2019 / Published online: 4 April 2020

(c) The Author(s) 2020

\begin{abstract}
Open innovation (OI) refers to the inbound and outbound flows of knowledge beyond the boundary of the organization, which can be in the form of pecuniary or non-pecuniary exchanges. Investigation into pecuniary and inbound innovation types has advanced rapidly, but non-pecuniary outbound OI (free revealing) has received less attention. Presenting a scale developed through a systematic literature review, expert testing and exploratory factor analysis, we show that revealing is reflected by five motivational factors, namely seeking complementary capabilities, product diffusion, strategic spillovers, product enhancement, and co-creation with firms. Regression models show that these factors influence the variety of innovation types and shareholder expectations of value capture through future returns.
\end{abstract}

Keywords Open innovation $\cdot$ Scale development $\cdot$ Revealing $\cdot$ Non-pecuniary $\cdot$ Openness

Rui Torres de Oliveira

rui.torresdeoliveira@qut.edu.au

Martie-Louise Verreynne

martie-louise.verreynne@ rmit.edu.au

John Steen

john.steen@ubc.ca

Marta Indulska

m.indulska@business.uq.edu.au

Jerad A. Ford

Jerad.Ford@csiro.au

1 RMIT University, Melbourne, Australia

2 Queensland University of Technology, Australian Centre for Entrepreneurship Research, Business School, Brisbane, Australia

3 University of British Columbia, Norman B. Keevil Institute of Mining Engineering, Vancouver, Canada

4 The University of Queensland, Business School, Brisbane, Australia

5 Commonwealth Scientific and Industrial Research Organisation, Canberra, Australia 


\section{Introduction}

In a dynamic and connected business environment firms cannot rely solely on their own internal resources to innovate. The open innovation (OI) literature investigates how firms bridge traditional boundaries to allow outside-in and inside-out knowledge flows (Chesbrough 2006), and whether they adopt a pecuniary or non-pecuniary approach to these transactions, resulting in four types of OI: revealing, selling, acquiring, and sourcing (Dahlander and Gann 2010). Of these four types of OI, it is well-understood why firms conduct in- or out-bound OI that involves financial transactions (pecuniary OI: selling and acquiring) (Chesbrough et al. 2014), and why and how they search for non-pecuniary (sourcing), inbound knowledge to use for innovation (Bogers et al. 2017). Yet, less is known about firms' motivations to share knowledge for free (Huizingh 2011; West and Bogers 2014) as it happens for example, in the information technology industry with open source software (Shah 2006; von Hippel 1988; West and Gallagher 2006; West and Lakhani 2008). We argue that this disproportionate focus on the inbound flow of knowledge fails to recognize that: (1) in- and out-bound OI is often coupled with bi-directional flows between firms (e.g. Laursen and Salter 2006), and (2) not all outbound innovation has an immediate aim of financial gain, but firms may indeed use revealing to enhance other aspects of their innovation processes (Henkel et al. 2014). Thus, while sharing for free occurs less frequently, it is important to open innovation researchers who want to understand the full picture of knowledge flows between firms.

A revealing strategy without an immediate financial gain, also termed "non-pecuniary outbound OI' or revealing (Dahlander and Gann 2010), has not been explored in the literature in a systematic way (West and Bogers 2014). Intuitively it seems less attractive to disclose knowledge for free since the mainstream strategy literature focuses on appropriability regimes that lead to value capture (Barney 1991; Teece 1986, 1988). Indeed, firms expect profits from innovation, and these may disappear if the innovation can be easily imitated (Baldwin and Von Hippel 2011; Machlup and Penrose 1950). The appropriability paradigm has therefore been largely unquestioned by scholars and policy-makers (Baldwin and Von Hippel 2011) since Schumpeter (1934) introduced innovation as an endogenous driver of growth into the economics literature. For example, patents are granted to firms as an encouragement to innovate because it allows them to capture returns from their investments. Yet, innovation is not restricted to market-based, pecuniary transactions. Revealing has therefore been recognized as being essential for the buying and selling of intellectual property long before the advent of what we now call 'open innovation'.

From a theoretical perspective, individuals and firms differ in why they reveal without immediate financial return (Alexy 2009). Through a systematic review of the motivation and innovation literatures, we identified that individuals reveal as part of: (1) reputationbuilding initiatives that signal proficiency for career advancement, (2) community reciprocity related to networking, and (3) utilitarianism that may lead to future entrepreneurial activities (Choi and Yi 2015). Organizations reveal to: (1) disclose problems (e.g. Alexy et al. 2013); (2) seek capabilities (e.g. Harhoff et al. 2003); (3) co-create (e.g. Henkel et al. 2014); (4) enhance innovation activities (e.g. Dahlander and Gann 2010); (5) diffuse knowledge (e.g. Gault and von Hippel 2009); and (6) create strategic spillovers (e.g. Harhoff et al. 2003).

While revealing occurs in practice, such as the now famous case of Tesla or where clinicians who share off-label applications for drugs and medical devices (von Hippel et al. 2017), the understanding of the practice and further development of this research area has 
been stifled by the lack of research infrastructure needed to undertake such studies. Our contribution is to develop a measurement scale for researchers who are, with the currently available measures, not able to fully understand the coupled relationships between inbound and outbound knowledge with innovation and performance. Being able to measure if firms reveal, and for what purpose they reveal, will help to understand how revealing supports other innovation processes and activities. It can also support firms, because while managers understand the benefits of a strategy of revealing that will allow the firm to create and capture value, they might need to convince stakeholders of its long-term benefits due to different time horizons between value creation and value capture (Chesbrough et al. 2018).

Thus, the purpose of this paper is to build a scale that can help academics and managers to measure firm-level revealing and then examine the relationship between revealing, innovation, and shareholder perceptions of value creation. To do so, we use DeVellis's (2016) four-step approach to scale development to design, develop and validate our scale, and, in the process, answer calls to better understand and measure revealing (e.g., Chesbrough et al. 2018; West and Bogers 2014, 2017) and outbound OI (Huizingh 2011). The remainder of this paper is organized as follows. Next we introduce the literature on revealing. We then describe our methods and findings and conclude with a discussion of our contributions and outline future research directions.

\section{Non-pecuniary open innovation}

\section{Open innovation}

Models of the innovation process have been evolving since the seminal work of Schumpeter (1934). While early explanations of innovation were limited to the linear commercialization of knowledge from within the firm, there has been growing recognition that innovation occurs as part of a system of knowledge and technology that crosses organizational boundaries (Dodgson 1994; Dodgson et al. 2011). OI recognizes knowledge flows in and out of the firm to combine firm capabilities and resources with those from external stakeholders (Chesbrough 2012; Dahlander and Gann 2010). It is defined as “...a distributed innovation process based on purposively managed knowledge flow across organizational boundaries using pecuniary and non-pecuniary mechanisms in line with the organization's business model" (Chesbrough et al. 2014: 17).

Such knowledge can be classified as pecuniary or non-pecuniary and in-bound or outbound (Dahlander and Gann 2010; West et al. 2014). Examples of pecuniary OI are inlicensing and out-licensing of intellectual property (Chesbrough et al. 2014). Non-pecuniary activities include, for example, the search for knowledge that can be of use in firms' innovation processes, or the act of selectively revealing details of innovations to others. Dahlander and Gann (2010) describe four types of OI: selling (outbound pecuniary); acquiring (inbound pecuniary); sourcing (inbound non-pecuniary); and revealing (outbound non-pecuniary) (see Table 1).

Past research on OI has emphasized selling, acquiring and sourcing (Chesbrough et al. 2014). This focus should not come as a surprise since selling or acquiring knowledge or ideas entails immediate value to the firm as it affects the quality of innovation output and innovation performance (Cammarano et al. 2017; Laursen and Salter 2006; Michelino et al. 2014), which in turn impacts positively on the firm's future financial returns. Similarly, sourcing also creates value, albeit delayed, from a knowledge input perspective. In contrast, 
Table 1 Open innovation typology. Source: Adapted from Dahlander and Gann (2010)

\begin{tabular}{lll}
\hline & Inbound innovation & Outbound innovation \\
\hline Pecuniary & $\begin{array}{l}\text { Acquiring } \\
\text { In-licensing, adopting or buying } \\
\text { expertise or technology from external } \\
\text { sources }\end{array}$ & $\begin{array}{l}\text { Selling } \\
\text { How firms protect, appropriate } \\
\text { value from, and commercialize } \\
\text { their intellectual property and } \\
\text { technological artifacts }\end{array}$ \\
Sourcing & $\begin{array}{l}\text { Revealing } \\
\text { knowaging existing external sources of }\end{array}$ \\
& $\begin{array}{l}\text { Sending knowledge to the external } \\
\text { environment selectively, in order } \\
\text { to spur problem solving or aid in } \\
\text { the diffusion of innovations }\end{array}$ \\
\hline
\end{tabular}

revealing knowledge that firms own, without it being associated with immediate value creation or value capture, implies risk to the firm and may seem illogical.

By giving knowledge away in such a manner, firms risk losing control of their knowledge, ideas or intellectual property without guarantees of financial returns. The literature has therefore defaulted to a position where revealing has received scant attention, and, as a result, we do not know from an empirical point of view how revealing relates to the creation and capture of economic value (Chesbrough et al. 2014; West and Bogers 2014, 2017). We also do not know how these outbound non-pecuniary flows are coupled with other forms of OI to support innovation performance and other forms of value creation in integrative models of external and internal knowledge as explained next (Chesbrough and Crowther 2006).

\section{Why reveal?}

Revealing knowledge without the expectation of monetary gain is inevitable in a connected business environment where frequent interactions with external parties often render mechanisms to protect knowledge impractical (Macdonald 1993). While pecuniary outbound OI (i.e. selling) usually involves transactions of licenses or patents, revealing frequently involves non-codified or tacit knowledge-sharing during interactions between the firm and external stakeholders. As opposed to being accidental, revealing can also be deliberate and can be used to create value in a strategic manner (Dahlander and Gann 2010). A well-known and recent example of strategic revealing is Tesla's open approach to intellectual property so that other businesses can develop complementary technologies that will improve Tesla's products (Tietze 2017).

Past literature points to some of the benefits that firms can expect from revealing (Henkel et al. 2014). From a marketing perspective, revealing can increase reputation (Henkel 2006), goodwill (West and Gallagher 2006), brand recognition (Dahlander and Magnusson 2008), and can be used to extend firms' target audience (West 2006). From a technological perspective, benefits can accrue when firms use crowdsourcing as a source of knowledge instead of trying to problem-solve internally or contracting a specialized supplier (Afuah and Tucci 2012; Piezunka and Dahlander 2015). While crowdsourcing focusses on inbound knowledge, it requires firms to first disclose specific technological problems and details to others. Revealing is also used strategically to get feedback from customers (Baldwin and Von Hippel 2011), manufacturers and even rivals (Harhoff et al. 2003). Furthermore, using 
continuous revealing of knowledge, lean start-up approaches put customers at the center of the start-up or spin-out process (Ries 2011, 2017). Other technical benefits of revealing include reducing manufacturing cost by disclosing technical problems or different potential development paths, developing standard components, improving reliability, and accessing new markets (Henkel et al. 2014). Furthermore, deliberate strategic revealing can be used as an initiating mechanism to activate collaborations (Alexy et al. 2013), which may enable firms to identify and successfully engage to create and capture value. Other benefits include 'servitization' (Vandermerwe and Rada 1988), which occurs when manufacturers provide customers with post-sales services. This can be seen by customers as a way of improving their knowledge based on the potential gains of free knowledge from manufacturers that can be further used, for example, for customers' own R\&D projects (Hakanen 2014). Firms also enter into deliberate revealing strategies when providing innovative bids for complex construction project contracts that require collaborative solution proposals (Davies et al. 2011).

In non-pecuniary settings, an important source of value comes from knowledge transfer between agents, either formally or tacitly, and in both directions. This can be a key competitive asset (Ritala et al. 2015). For example, a strategic alliance is a bilateral and mutually interactive process (Anderson and Weitz 1992) that leads to the acquisition of new capabilities through organizational learning and that enhances the firm's dynamic capabilities (Mowery et al. 1996). Therefore, there are tradeoffs between revealing and the types of pecuniary OI. These tradeoffs may not be immediate, yet are critical to better comprehend OI (Lamberti et al. 2017, Marcelino et al. 2015). Thus, while revealing remains underinvestigated, the practice has become well-established and therefore the development of research instruments to enable its study is timely.

\section{Scale development process}

To develop the revealing scale, we undertook a structured four-step process (DeVellis 2016). We first conducted a systematic literature review to identify and adapt reflective measures. We then engaged with experts $(n=13)$ through an online survey to refine these measures. Next, we developed a survey instrument that was used to test our scale. We then undertook rigorous empirical analysis of the results $(n=164)$ to arrive at the final scale. This approach allowed us to examine the operational, nomological and predictive validity of the scale (DeVellis 2016), as summarized in Table 2 and explained in the remainder of this section.

\section{Step 1: Literature review of the dimensions of revealing}

Individuals and firms differ in how and why they deliberately reveal knowledge. For firms, revealing can be a strategic decision, which we examined through an extensive and systematic literature review. We reviewed the literature according to an explicit and rigorous methodology (e.g. Bakker 2010; Newbert 2007) of planning, execution, and reporting. This allowed us to synthesize past research and prevent unproductive repetition of efforts, while grounding future research in the OI literature (Tranfield et al. 2003). As seen in the first three columns of Table 3, the dimensions of revealing that emerged from the literature review were: problem disclosure, capability-seeking, co-creation, enhancement, diffusion, and strategic spillovers. 
Table 2 Scale development process

\begin{tabular}{|c|c|}
\hline Stages of scale development process & Details \\
\hline Stage 1: Construct definition and item generation & $\begin{array}{l}\text { Extensive and systematic literature review, six themes } \\
\text { emerged } \\
\text { Operationalize themes as constructs, define each } \\
\text { construct and its dimensions, which were operation- } \\
\text { alized as items: } \\
\text { Problem disclosure with } 4 \text { items } \\
\text { Capability-seeking with } 4 \text { items } \\
\text { Co-creation with } 6 \text { items } \\
\text { Enhancement with } 4 \text { items } \\
\text { Diffusion with } 4 \text { items } \\
\text { Strategic spillovers with } 4 \text { items }\end{array}$ \\
\hline Stage 2: Expert opinion & $\begin{array}{l}13 \text { interviews with industry and academic specialists, } \\
\text { consisting of: } \\
\text { Senior managers from multinational firms } \\
\text { Patent attorneys } \\
\text { Innovation specialists faculty members } \\
\text { All } 26 \text { items remained but several were refined }\end{array}$ \\
\hline Stage 3: Data collection and item refinement & $\begin{array}{l}\text { Survey to } 164 \text { senior managers level of listed firms } \\
\text { Preliminary reliability tests } \\
\text { Exploratory factor analysis } \\
\text { Confirmatory factor analysis } \\
\text { Collection of secondary data (not used here) }\end{array}$ \\
\hline Stage 4: Scale validation & $\begin{array}{l}\text { Convergent validity } \\
\text { Divergent validity } \\
\text { Nomological (predictive) validity }\end{array}$ \\
\hline
\end{tabular}

Problem disclosure describes how firms expose internal knowledge, usually to solve a technical problem, to other parties. Problem disclosure enables firms to get third party input when they are unable to solve a specific problem internally and are therefore willing to disclose details of their innovation-related challenges (Dodgson et al. 2006; Henkel 2006). It may also enable them to truncate their innovation process (Alexy et al. 2013; Lopez-Vega et al. 2016). Moreover, firms disclose different potential trajectories or aspirational technologies to test the market and wait for feedback before making final decisions (Jeppesen and Lakhani 2010; Nickerson and Zenger 2004; Piezunka and Dahlander 2015).

Capability-seeking refers to a firm's search for complementary capabilities that are known to be critical dimensions of the innovation process (Alexy et al. 2013). To do this, firms need to locate, explore, and absorb those complementary capabilities from the market (Chesbrough and Crowther 2006). Capabilities can be located in individuals with high value to the firm's innovation process (Henkel et al. 2014) or in users, suppliers, or competitors (Alexy and Reitzig 2013; Dodgson et al. 2007). Often complicated to accomplish, capability-seeking leads firms to selectively disclose aspects of their innovative activities to attract or gain access to external agents as potential collaborations (Vanhaverbeke 2006).

Co-creation reflects the identification of potential agents with whom firms may want to collaborate more formally during the innovation process. An effective collaboration 


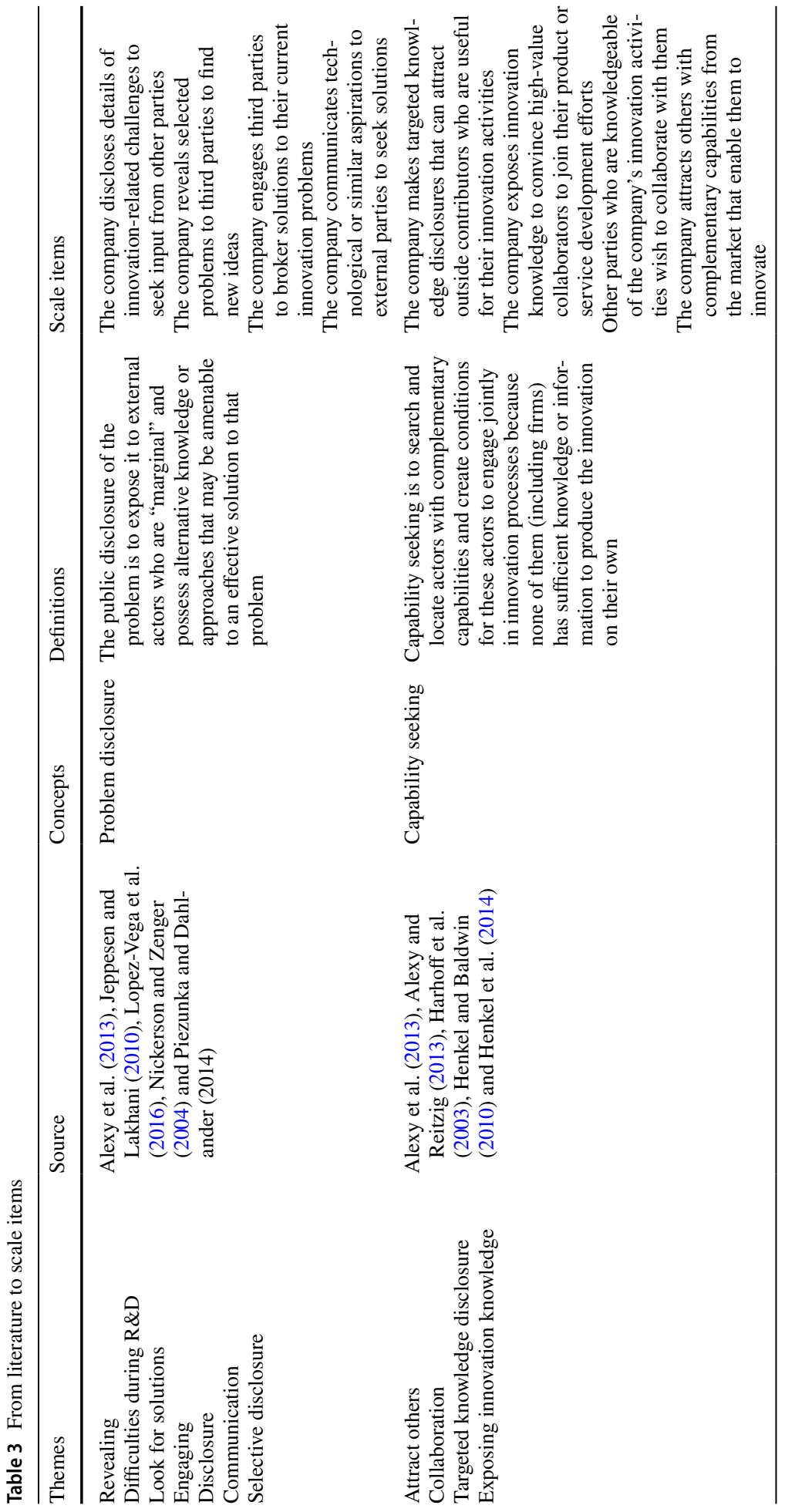




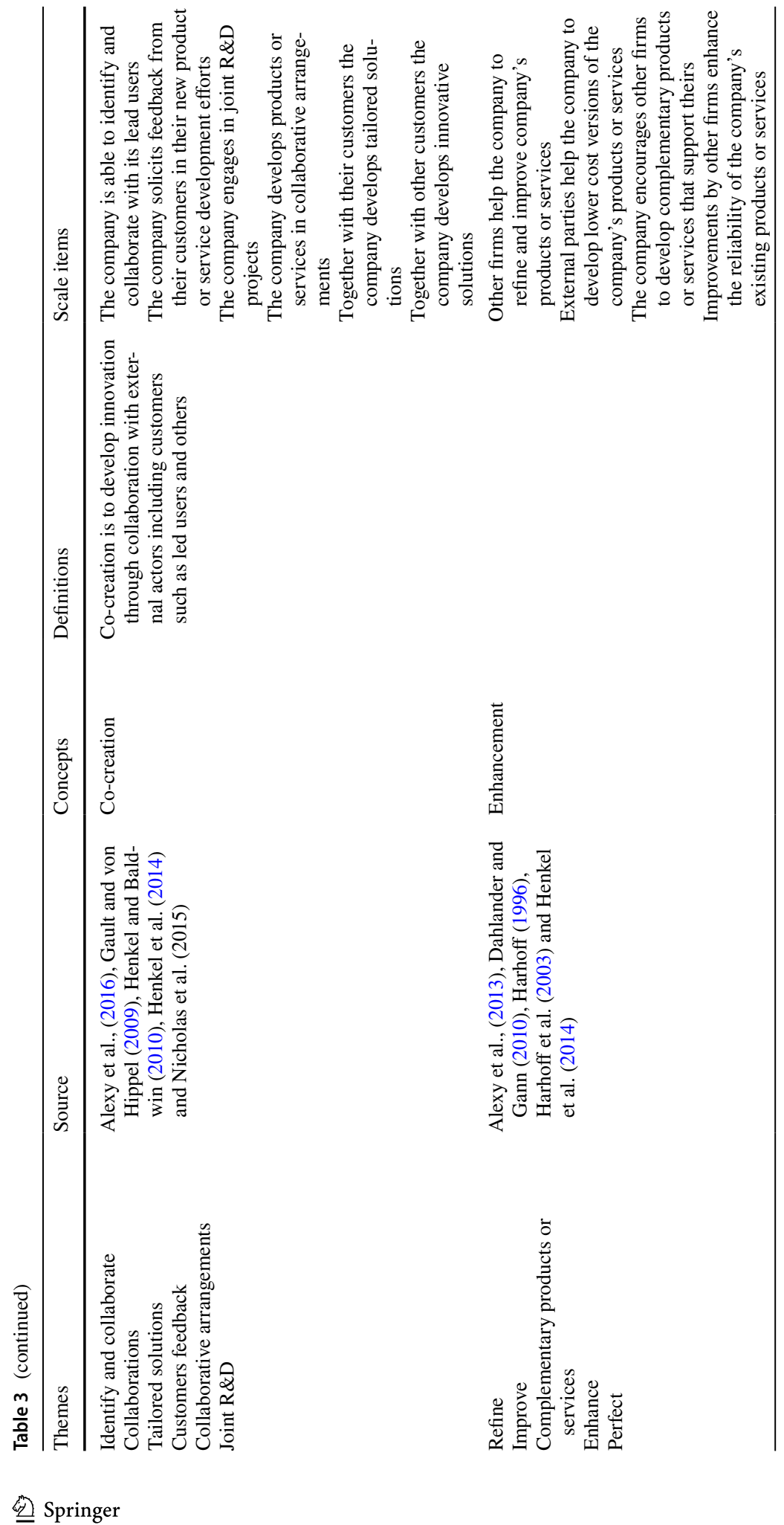




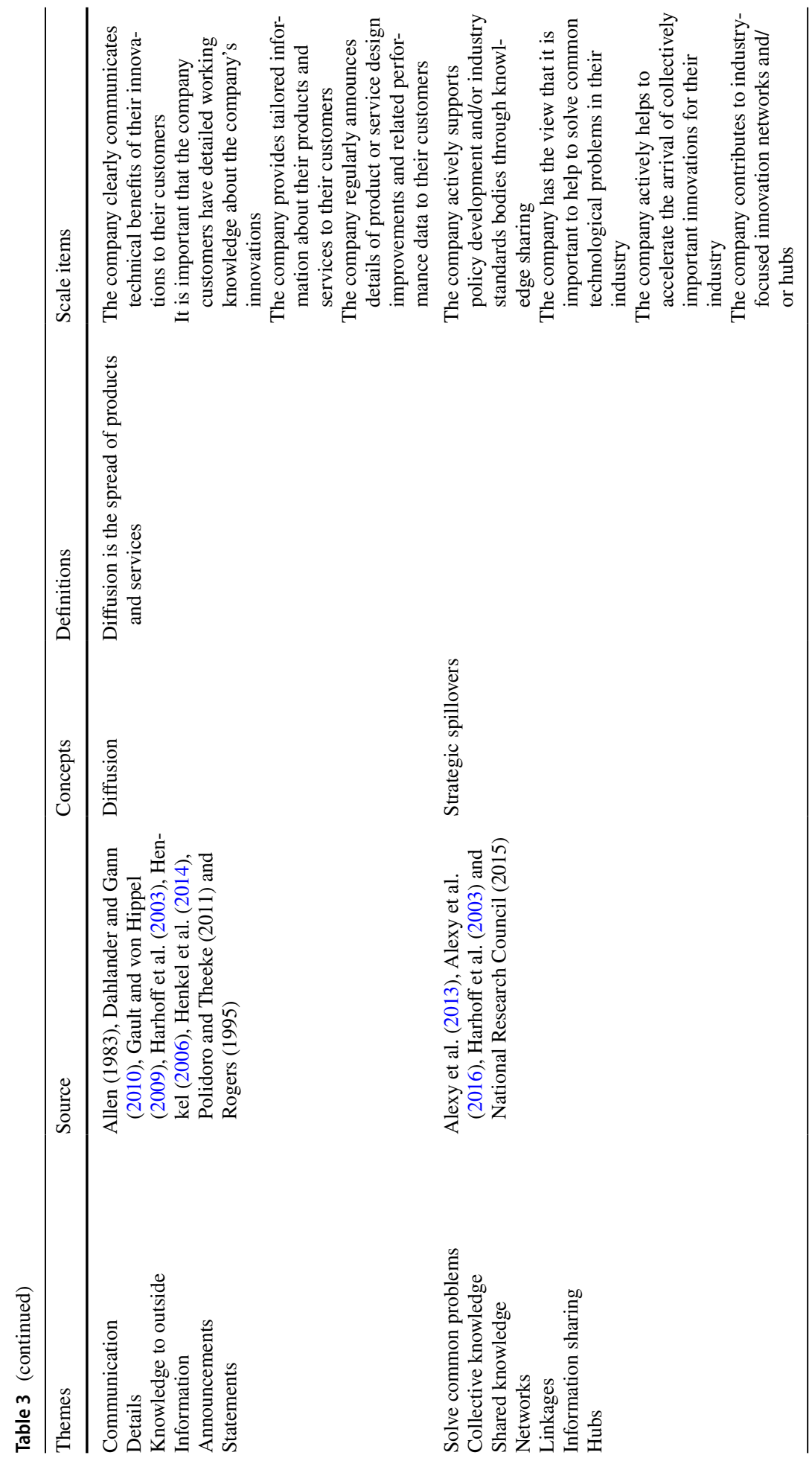


entails a dynamic process of revealing and absorbing knowledge (Harhoff et al. 2003; Steen et al. 1998). The literature refers most often to co-creation relationships with customers who have a critical view of the firm's new products or services (Dhanaraj and Parkhe 2006; Kale et al. 2000; Von Hippel 1986). However, co-creation extends beyond customers and can occur with a variety of stakeholders and market agents (Parent et al. 2000) to collaboratively develop products and services (Alexy et al. 2016). External knowledge and its sharing is considered to be a critical precondition to firm innovation (Henkel and Baldwin 2010; Von Hippel 1986). Independently of the arrangements and the agents involved, empirical evidence (Chesbrough 2006; Huizingh 2011) shows that for collaborative arrangements to work, there is a need for transactions between agents that both parties consider to be valuable. In non-pecuniary settings an important part of value comes from knowledge transfer between agents in a formal and/or tacit way and in both directions, which is known to be a key competitive asset (Ritala et al. 2015). In strategic alliances, for example, the acquisition of new capabilities through organizational learning enhances the firm's dynamic capabilities (Mowery et al. 1996).

Enhancement refers to the use of external help to improve existing products or services. Similar to co-creation, firms are frequently open to outside inputs, which entails disclosure to the external agents of knowledge that the firm could have chosen to keep internal. This externalization of knowledge can happen with the objective of improving the reliability of the firm's existing products or services (e.g., Cohen and Levinthal 1990; Hamel 1991; Kogut 1988), refining and improving the firm's products or services (Henkel et al. 2014), lowering the costs of products or services (Dahlander and Gann 2010; Henkel et al. 2014), or even encouraging external agents to develop complementary products or services that support or complement the firm's products or services (Harhoff et al. 2003).

Diffusion refers to the spread of products and/or services and relates to the firms' decision to charge for access to, and use of, their ideas, knowledge or innovations. Such a decision constrains the diffusion of innovation, which can be seen as a decision about receiving immediate rents versus delaying potential rents. If the option is to push for free dissemination of innovation, it implies disclosing knowledge without immediate financial gain. This option can lead to faster product/service adoption, which in turn can potentially generate larger future rents (Alexy et al. 2013; Harhoff 1996; Henkel et al. 2014). A classic example is an online platform, such as Snapchat, where the value of the platform is based on the number of users. Firms can use this to communicate the technical benefits of their innovation to their customers for free (Peres et al. 2010). Furthermore, firms can release information on future innovations to draw clients into their ecosystem (Henkel et al. 2014; Rogers 2010). Another way that firms can incentivize diffusion is by providing tailored information about their products/services to selected customers, with a clear intention to capture their attention (Gault and von Hippel 2009; Henkel 2006). Finally, firms can regularly announce information about improvements to their products or services and related performance data to their customers (Dahlander and Gann 2010; Harhoff et al. 2003; Henkel et al. 2014).

Strategic spillovers see firms reveal knowledge for the greater good of a fledgling industry. Strategic spillovers have no immediate benefits, but firms can benefit by, for example, working with policy-makers and industry associations on the development of policies and/ or industry standards. Harhoff (1996) describes this as a process that benefits others in the firm's industry or supply-chain, such as increased product quality, lower R\&D sunk costs, and easier entry into the industry. For this type of engagement to occur, firms need to disclose knowledge selectively to officials, industry experts, and even competitors (Gault and von Hippel 2009). Such selective revealing can also be related to the development and 
creation of industry-focused innovation networks and/or hubs (Harhoff et al. 2003). In fact, firms can collectively push for important innovations for their industry to, for example, build or establish standards and/or design dominance, or improve the industry's goodwill (Alexy et al. 2016). Finally, firms can reason that it is important to help solve problems that are common to their industry and in this process reveal selective and unrelated knowledge on specific matters without jeopardizing rents (Alexy et al. 2013; Harhoff et al. 2003).

The literature therefore suggests the existence of six distinct dimensions of revealing. We used these dimensions as a basis to develop a robust multi-item scale of twenty-six items distributed as follows: problem disclosure (4), capability-seeking (4), co-creation (6), enhancement (4), diffusion (4), and strategic spillovers (4) (see Table 3).

\section{Step 2: Expert opinion}

Our next step was to seek input on our scale from a group of experts, using an online survey. The 13 individuals who agreed to participate in the expert study included senior managers from large multinational companies, patent attorneys, academics with expertise in the field of OI, and staff from public innovation hubs and technology transfer offices. The experts were briefed on our reflective items as well as on the six revealing constructs. We asked them to rate and provide suggestions on each item and construct. We then followed Stratman and Roth's (2002) approach to discard items if over $20 \%$ of experts rated the item as somewhat or not representative. Through this process none of the items were discarded, but several items were refined to address feedback.

\section{Step 3: Survey}

The survey was divided into sections that considered the general characteristics of the firm, our scale items, other aspects of innovation, the competitive situation, and financial performance. We used multi-item scales to measure the dimensions of revealing and to allow us to validate our reflective measures (Hambrick and Mason 1984). Each question was rated on a five-point Likert scale that ranged from "strongly disagree" to "strongly agree". To prevent common method bias we used different strategies during the design of the questionnaire (Rindfleisch et al. 2008). First, each of the dependent and independent variables used unique instructions. Second, we used different scale endpoints depending on the type of variable. Third, we rotated the order of multi-item measures in the scale to prevent any type of order effect.

We used a telephone survey to test our scale, targeting executive managers and/or R\&D senior managers from Australian Stock Exchange (ASX) listed companies during 2016. Senior managers are key informants for the type of knowledge that we sought to obtain because strategic decisions of firms are made at this level (Zaichkowsky 1985). The survey was administered using a computer-aided telephone interviewing (CATI) subcontractor who was previously evaluated and who uses highly skilled staff to conduct surveys. Surveys took on average 25 min to complete. The CATI operator made 246 attempts to contact firms and acquired 164 useable responses, achieving an acceptable 67\% response rate (Anderson and Gerbing 1988).

The firms in our sample had an average of 1919 employees (standard deviation of 4450 due to the fact of some firms had over 20,000 workers), were 30 years old (standard deviation of 32 due to the fact that some firms were older than 100 years). Eighty-seven percent of the firms engaged in R\&D in the last financial year, $73 \%$ of the firms had external R\&D 
spending (which represented an average of $22 \%$ of their total R\&D budget), $46 \%$ of the firms belonged to the manufacturing sector, $17 \%$ to information media and telecommunications and $6 \%$ to health care and social assistance. All responses were from senior managers.

\section{Step 4: Scale validation}

To establish the reliability and validity of our scale, we undertook three types of analyses. Exploratory factor analysis (EFA) was used to explore our data (Baruch 1999) and establish the dimensions of our scale. This was followed by confirmatory factor analysis (CFA) during which we fitted a series of one-factor models to investigate the uni-dimensionality of the scale (Churchill 1979). We then specified and tested variations of a multifactor model to establish the convergent and divergent validity of the subscales. Our final assessment of the reliability and validity of our constructs was done by estimating a series of structural equation models to establish predictive or nomological validity (Gerbing and Anderson 1988).

\section{Exploratory factor analysis}

We started with the analysis by investigating the correlations between items. As expected when producing representative factors, many items were correlated (see Table 4) (Hair et al. 1998). We next conducted EFA using SPSS Version 24. Principal axis factoring with Varimax rotation was used to extract the factors (Hair et al. 1998). Analyses of the scree plot suggested that a six-factor solution had an eigenvalue higher than one and explained $60.1 \%$ of the total variance $\left(\mathrm{KMO}=0.883\right.$; Bartlett's test of spherity: $X^{2}(325)=1853.164$, sig. 0.000 ) with a high correlation between variables. Further analysis of the different items led us to identify that one item was loading below the critical factor loading of 0.40 and, following Cattell (1966), we decided to remove it. After re-running the EFA another item was deleted. There was no strong theoretical justification to keep either of these items (Hair et al. (1998)). The deletions resulted in five factors representing an eigenvalue higher than one and explaining $59.4 \%$ of the total variance $\left(\mathrm{KMO}=0.885\right.$; Bartlett's test of spherity: $X^{2}$ $(276)=1737.273$, sig. 0.000) with high correlations between the variables with which we proceeded (see Table 4).

\section{Confirmatory factor analysis}

To test the stability, fit and uni-dimensionality of the measurement model we proceeded to conduct CFA (Hair et al. 1998), using AMOS 24 to examine each of the five factors or subscales from the EFA. Following Anderson and Gerbing (1988) we used several fit indices to evaluate the CFA model, such as: (1) absolute fit measures-assesses how well the constructs fit the sample data and can be measured with statistics such as Chi-square $\left(\chi^{2}\right)$, a normed $\chi^{2}$, goodness-of-fit index (GFI), and the root mean square error of approximation (RMSEA) — values below 0.05 in RMSEA and over 0.8 in GFI indicate good absolute model fit; (2) incremental fit measures-measured by the normative fit index (NFI) and the comparative fit index (CFI) with CFI values above 0.92 being associated with good incremental fit; and (3) parsimony fit measures - which assess a model's fit relative to its complexity - usually measured by using an adjusted goodness-of-fit index (AGFI) or a parsimony normed fit index (PNFI) — as a rule of thumb, values higher than 0.9 generally represent better model fit. 


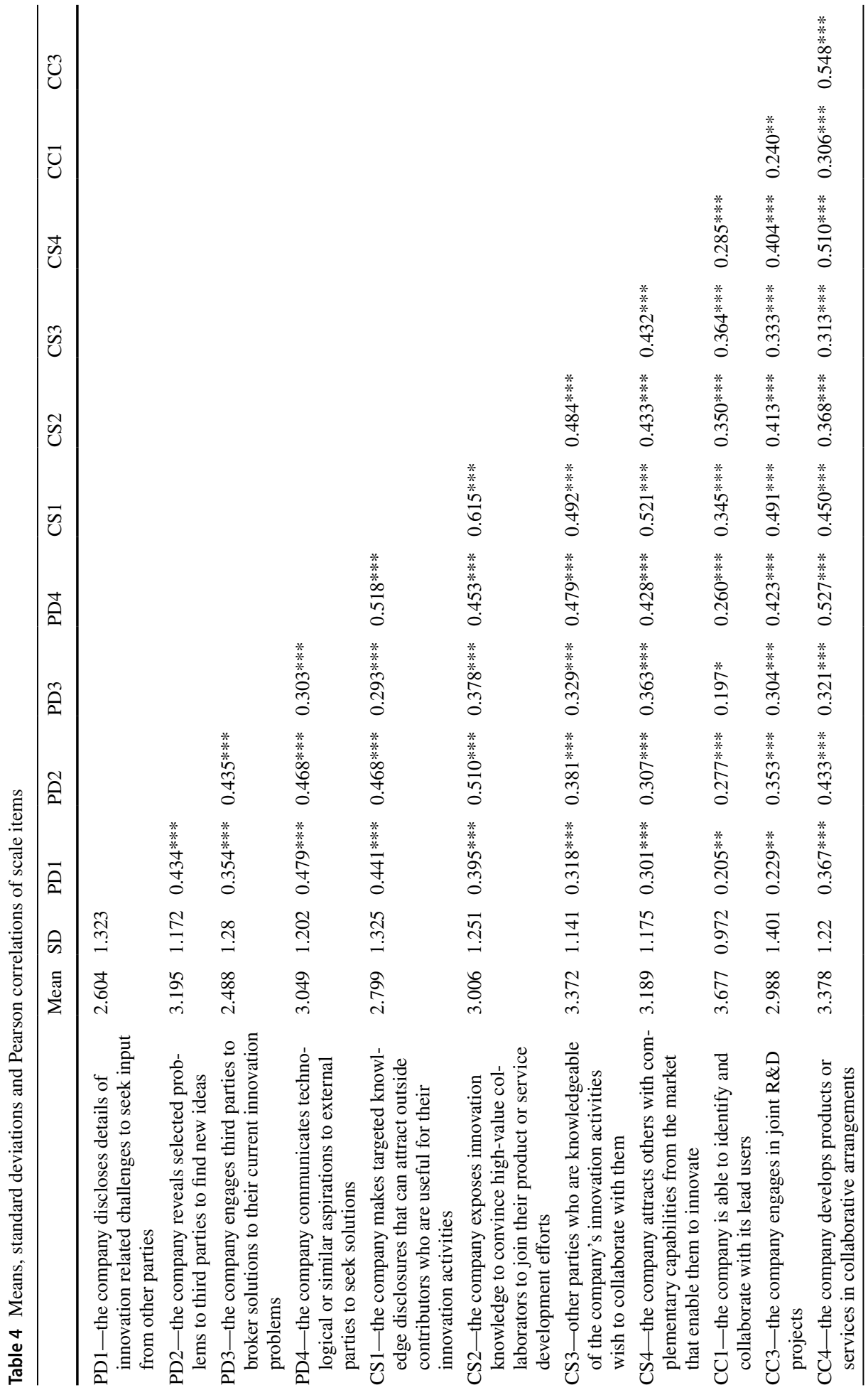




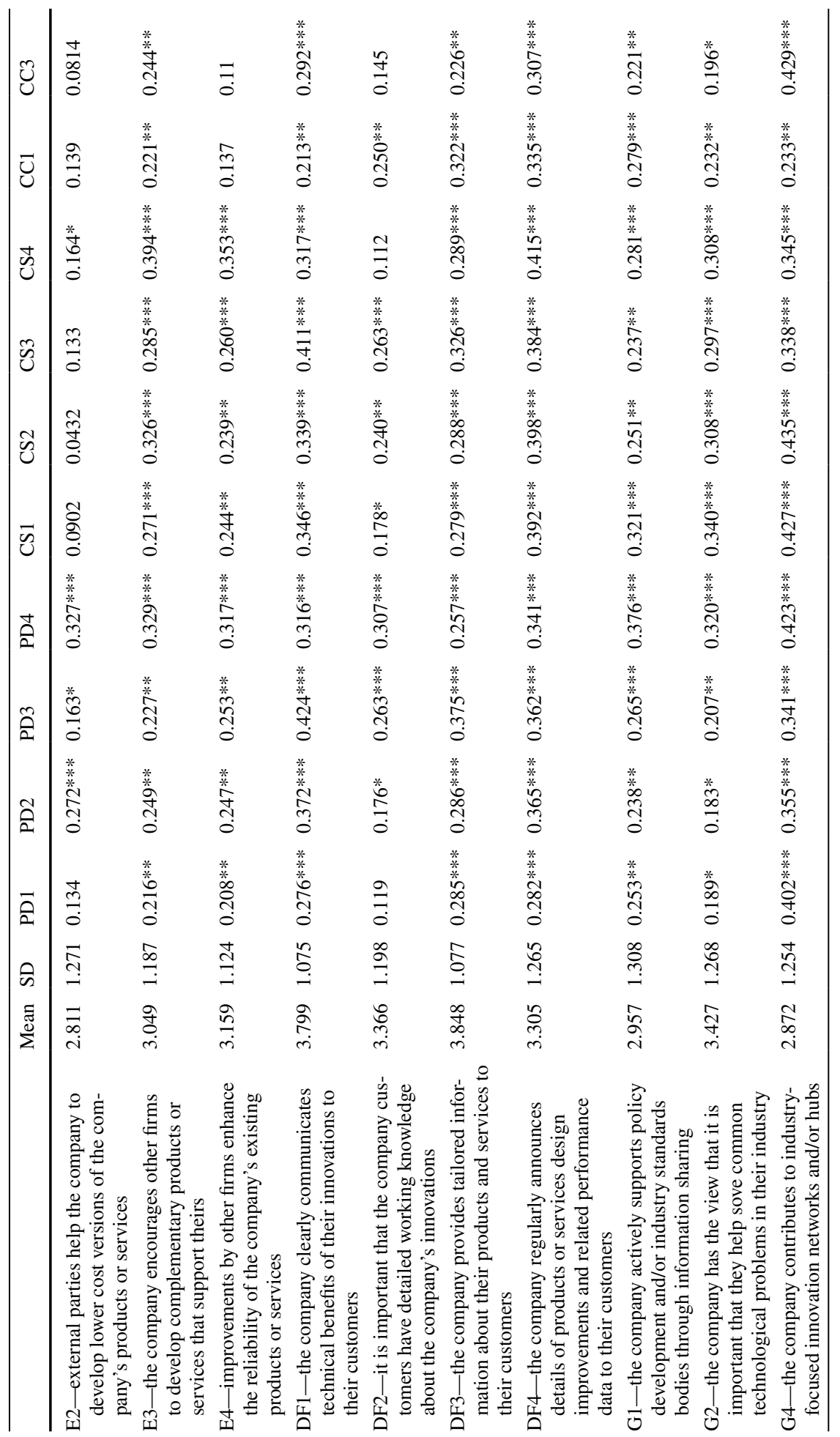




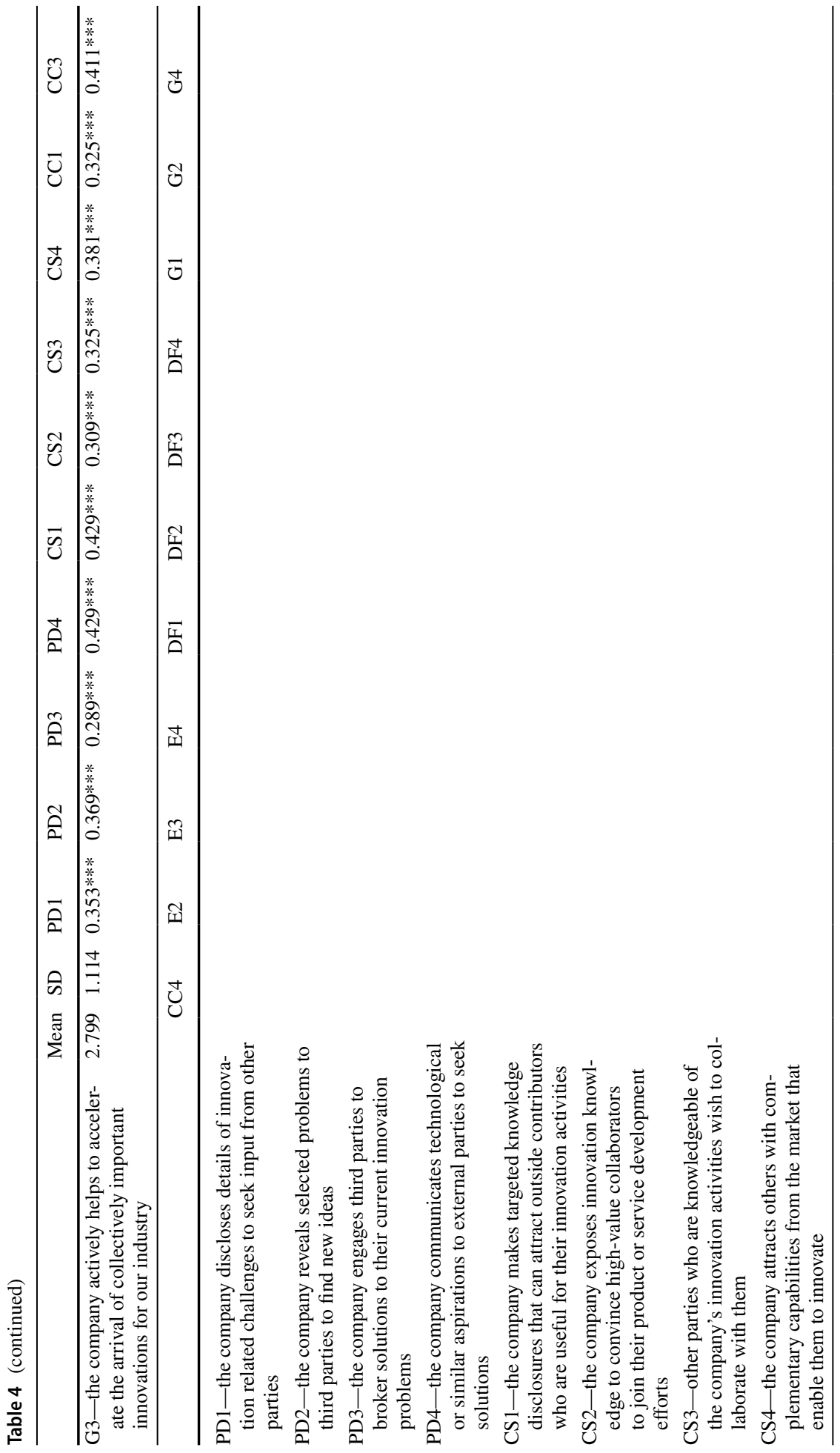




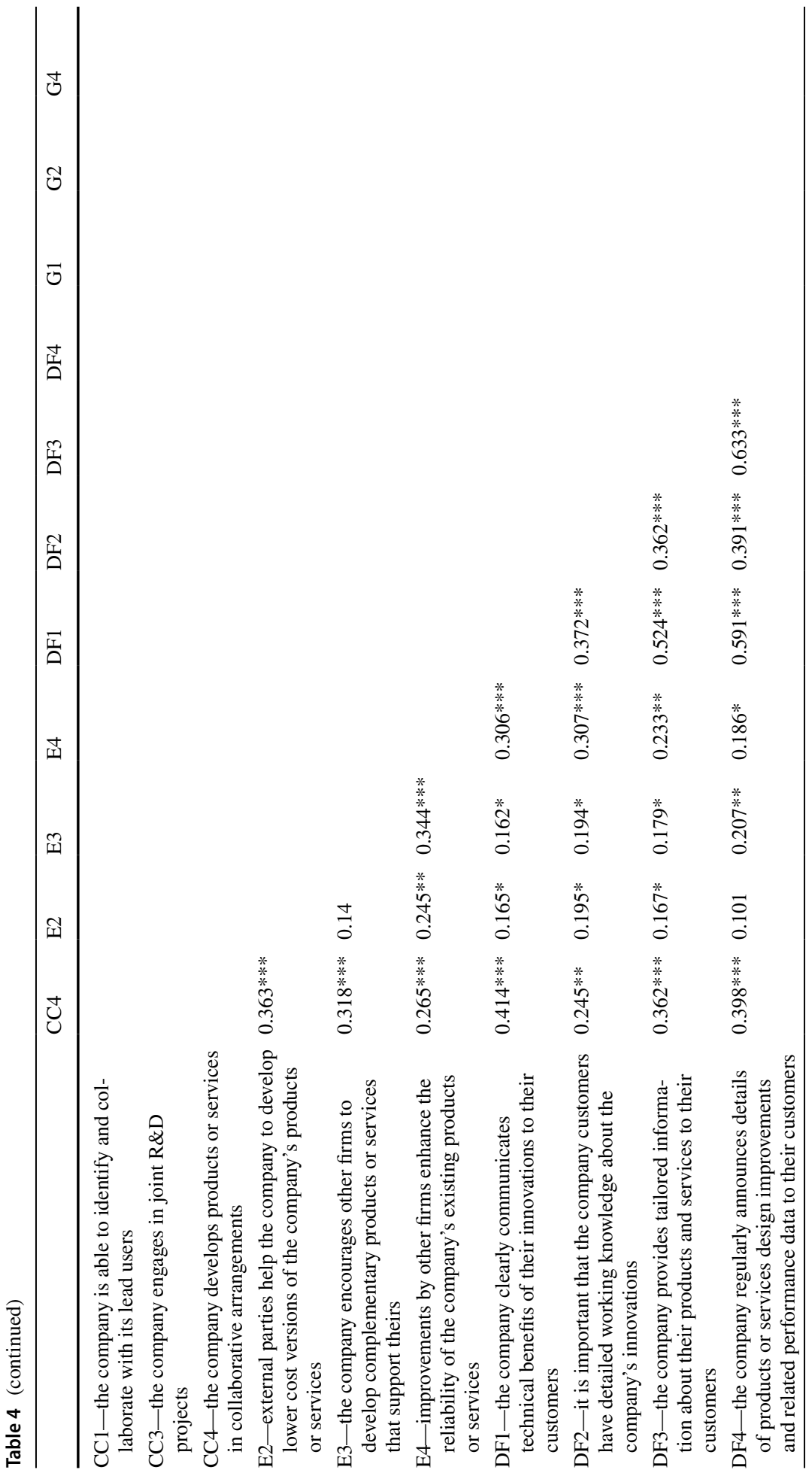




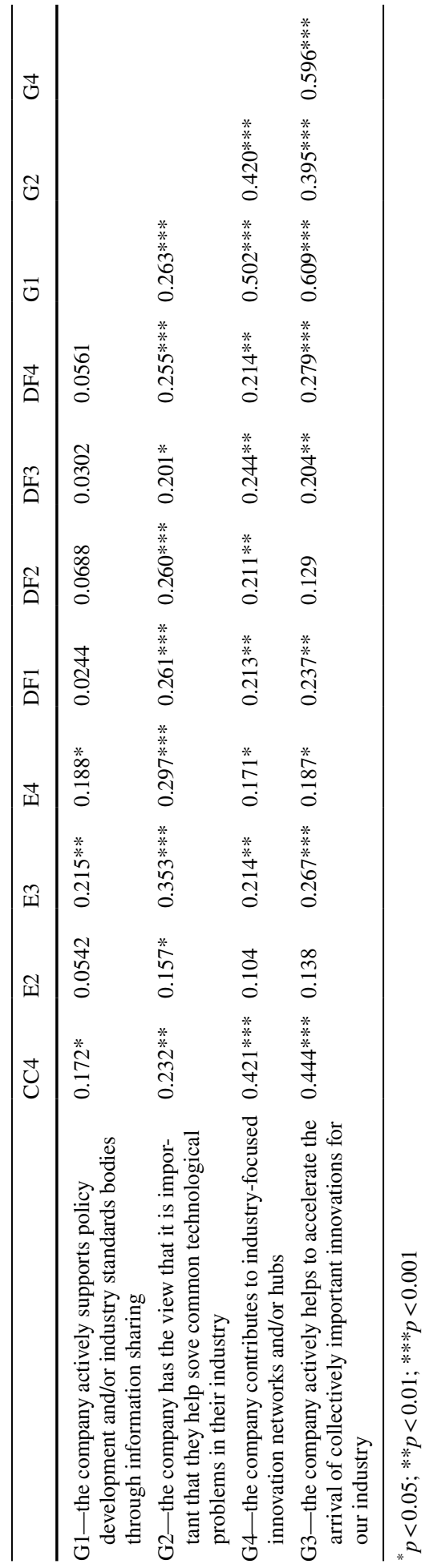


We followed the domain sampling paradigm to specify models with a classic reflective structure (Bollen 1983) based on our reading of the literature, which implies that we do not view our items as a definitive statement of the universe of all possible items (Verreynne et al. 2016). Our view in this regard is supported by the high inter-item correlations and the fact that each item was distinct from the others. Each of the subscales was specified as a set of observed variables that were a function of the latent variable and its measurement error, using maximum likelihood with sample co-variances as input. Good fit of each model would indicate that a hypothesis of uni-dimensionality could be rejected.

The first factor represented two of the original constructs-capability-seeking (three of the four initial items) and problem disclosure (all initial items), and we termed it complementary capabilities. We removed one of the items that was not theoretically well related with our new construct, as well as one item that was not significant. The items contained in each sub-scale are shown in Table 5. The fit statistics $(p=0.202$; RMSEA $=0.046 ; \mathrm{GFI}=0.973 ; \mathrm{CFI}=0.989)$ indicated good fit. The standardized

Table 5 Final scale

\begin{tabular}{|c|c|}
\hline Construct & Item \\
\hline Complementary capabilities & $\begin{array}{l}\text { The company discloses details of innovation-related challenges to seek input } \\
\text { from other parties } \\
\text { The company reveals selected problems to third parties to find new ideas } \\
\text { The company communicates technological or similar aspirations to external } \\
\text { parties to seek solutions } \\
\text { The company makes targeted knowledge disclosures that can attract outside } \\
\text { contributors who are useful for their innovation activities } \\
\text { The company exposes innovation knowledge to convince high-value collabo- } \\
\text { rators to join their product or service development efforts } \\
\text { Other parties who are knowledgeable of the company's innovation activities } \\
\text { wish to collaborate with them }\end{array}$ \\
\hline Diffusion & $\begin{array}{l}\text { The company clearly communicates technical benefits of their innovations to } \\
\text { their customers } \\
\text { It is important that the company customers have detailed working knowledge } \\
\text { about the company's innovations } \\
\text { The company provides tailored information about their products and services } \\
\text { to their customers } \\
\text { The company regularly announces details of product or service design } \\
\text { improvements and related performance data to their customers }\end{array}$ \\
\hline Strategic spillovers & $\begin{array}{l}\text { The company actively supports policy development and/or industry standards } \\
\text { bodies through information sharing } \\
\text { The company actively helps to accelerate the arrival of collectively important } \\
\text { innovations for their industry } \\
\text { The company contributes to industry-focused innovation networks and/or } \\
\text { hubs }\end{array}$ \\
\hline Inter-firm co-creation & $\begin{array}{l}\text { The company engages in joint } R \& D \text { projects } \\
\text { The company develops products or services in collaborative arrangements } \\
\text { The company attracts others with complementary capabilities from the mar- } \\
\text { ket that enable them to innovate }\end{array}$ \\
\hline Enhancement & $\begin{array}{l}\text { The company encourages other firms to develop complementary products or } \\
\text { services that support theirs } \\
\text { Improvements by other firms enhance the reliability of the company's exist- } \\
\text { ing products or services } \\
\text { The company has the view that it is important to help to solve common tech- } \\
\text { nological problems in their industry }\end{array}$ \\
\hline
\end{tabular}


regression weights ranged between 0.60 and 0.77 . We squared the standardized regression weights to measure the item reliability and found that they ranged from 0.36 to 0.59 . Some items therefore had more measurement error than explained variance, but because we were concerned with validity, all items were retained.

The second factor represented items from diffusion (all initial items) and co-creation (with customers) (all items for co-creation with customers). Two of the three items from customer co-creation had high standardized residual co-variances and we decided to drop them, leaving only one item for co-creation. From a theoretical perspective we decided to delete this item as well. The model had a good fit $(p=0.848$; RMSEA $=0.000 ; \mathrm{GFI}=0.998 ; \mathrm{CFI}=1.000$ ). Similarly to the previous factor, we squared the standardized regression weights (ranging between 0.48 and 0.83 ) and found them to range from 0.26 to 0.69 .

Because all the co-creation with customers items were deleted from the second factor, we decided for the sake of completeness to create a new subscale called customer co-creation. This sub-scale included the following items: "together with other customers the company develops innovative solutions"; "the company solicits feedback from their customers in their new product or service development efforts"; "together with the company customers the company develops tailored solutions". The RMSEA of this model indicated poor fit, even though other fit measures were in the acceptable range $(p=0.060 ; \mathrm{RMSEA}=0.125 ; \mathrm{GFI}=0.986 ; \mathrm{CFI}=0.960)$. Further, since this sub-scale did not emerge as a separate factor in the exploratory factor analysis, we decided not to include it in further models.

The third factor represented strategic spillovers (all initial items). The model had good fit considering that it has only three items $(p=0.628$; RMSEA $=0.000$; $\mathrm{GFI}=0.999 ; \mathrm{CFI}=1.000)$. The standardized regression weights ranged between 0.70 and 0.85 . When squaring the standardized regression weights to measure item reliability, it was in the acceptable range of 0.49-0.72.

The fourth factor was now termed inter-firm co-creation. The model had good fit $(p=0.563$; RMSEA $=0.000 \mathrm{GFI}=0.999 ; \mathrm{CFI}=1.000)$. The standardized regression weights ranged between 0.62 and 0.80 and squaring them led to a range of $0.38-0.64$, which taken together with other fit measures, were viewed as acceptable.

The last factor is enhancement (three of four initial items). The fit statistics were again within the acceptable range $(p=0.582 ; \mathrm{RMSEA}=0.000 ; \mathrm{GFI}=0.999$; $\mathrm{CFI}=1.000$ ). The standardized regression weights ranged between 0.52 and 0.64 . When squaring the standardized regression weights we measured the item reliability, which in this case ranged from 0.27 to 0.41 . As before, we deemed this acceptable taking into account the other fit measures. The final values to test the uni-dimensionality and reliability of the scale can be found in Table 6 .

Table 6 Scale uni-dimensionality and reliability analysis of each factor

\begin{tabular}{lllllrr}
\hline Factor & No. of items & $\begin{array}{l}\text { Cronbach's } \\
\text { alpha }\end{array}$ & RMSEA & $P$ & CFI & GFI \\
\hline Complementary capabilities & 6 & .84 & .046 & .202 & .989 & .973 \\
Diffusion & 6 & .81 & .000 & .848 & 1.00 & .998 \\
Strategic spillovers & 3 & .79 & .000 & .628 & 1.00 & .999 \\
Inter-firm co-creation & 3 & .74 & .090 & .129 & .988 & .997 \\
Enhancement & 3 & .60 & .000 & .582 & 1.00 & .999 \\
\hline
\end{tabular}




\section{Convergent and divergent validity}

The next step was to test the convergent and divergent validity of the model. For that, we created two new models. We specified a multi-factor model (Model 1) that included all five subscales with their items and in which the subscales were correlated. Estimating this model yielded a $\chi^{2}$ value of $133.27(d f=121, p=0.210)$; RMSEA $=0.025$; GFI $=0.927$; and $\mathrm{CFI}=0.989$. The regression coefficients were significant at 0.001 level and the standardize coefficients ranged from 0.47 to 0.81 , with the squared regression coefficients ranging from 0.22 and 0.66 , which provides further evidence of convergent validity at the item level. These results indicate good fit, thus the model parameters warrant interpretation, which, in turn, indicates that all the items used are valid and should be used in our final scale.

Following Jöreskog and Sörbom (1996) we can test divergent validity if the subscales are not the same constructs. To test this, we fixed the correlation between each two subscales to unity (i.e., one) and re-estimated the model. We further compared the fit of the fixed model(s) to the free model (i.e., the original multi-factor model). If the free model has better fit to the sample data than the fixed model(s) then we can reject the hypothesis that the subscales are the same constructs. Since we have five constructs, we performed ten sets of correlations and comparisons. In all ten cases the free model achieved better fit to the sample data than the fixed model(s). Thus, we can conclude that divergent validity was achieved for the five subscales.

Model 2, a higher order factor model, helped to establish that the specific construct was of high interest and that the content domain from which the items were sampled was not too restrictive, thus addressing discriminant and convergent validity (Schreiber et al. 2006; Yoo and Donthu 2001). This model allowed the level of analysis to shift to a more broadly defined construct, where the first-order factors have their estimated construct correlations implicitly adjusted for attenuation due to measurement error (Gerbing and Anderson 1988). Thus, Model 2 had a higher order latent variable that represents an overall measuring of revealing and yielded a $\chi^{2}$ value of $137.01(d f=122, p=0.167)$; RMSEA $=0.027$; $\mathrm{GFI}=0.924$; and $\mathrm{CFI}=0.987$, representing good data fit.

Finally, we analyzed the regression coefficients between the higher order factor and the five sub-factors to measure the validity of the dimensions (Gerbing and Anderson 1988), having all five regression coefficients significant $(p<0.001)$, indicating discriminant validity (Bagozzi et al. 1991). Based on Models 1 and 2 we can establish the convergent and divergent validity of our proposed five subscales and move to nomological or predictive validity next.

\section{Nomological (predictive) validity}

Predictive or nomological validity shows that a new construct relates to existing constructs in an expected way, and is therefore an important step in establishing the validity of a new scale. To assess the predictive validity of our revealing scale we constructed a structural model that included our five revealing constructs and tested them against two separate dependent variables - innovation breadth and Tobin's Q.

Innovation breadth was based on data collected in the survey. This variable was measured following Laursen and Salter (2006) who similarly introduced innovation search breadth, and Love et al. (2009) and Damanpour et al. (2009) who also used 
measures of innovation based on counts of the number of types of innovation a firm introduced. In our case, we used seven items related with different types of innovations that were each coded as a binary variable (zero indicating no innovation of this type was introduced and one the affirmative). These items were summed, ranging from zero to seven for firms that introduced all innovation types. Similarly to previous commentary (Garriga et al. 2013; Leiponen and Helfat 2010), we argue that revealing has implications for innovation breadth based on the fact that revealing increases the likelihood of introducing a broader range of innovations because it facilitates the exchange of a large amount of knowledge. When firms reveal they do so with selected stakeholders and thus expect feedback that will be used internally. More recently, Laursen and Salter (2014) established relationships between OI and the different types of innovation suggesting that revealing will be influential in different types of innovations.

We estimated two full structural equation models, regressing innovation breadth as a dependent variable on the five revealing sub-scales. The two models differed in how the correlations among sub-scales are presented in an attempt to account for the shared influence of the sub-scales. First, we used the most parsimonious specification setting the correlations to zero (Model 3a). With no correlations among independent or dependent variables, there were 10 regression coefficients, essentially representing a multivariate regression model that controls for measurement error. Model 3a yielded a chi-square of $427.71(d f=145, p=0.000)$ with $\mathrm{RMSEA}=0.103$; $\mathrm{GFI}=0.766$; $\mathrm{CFI}=0.759$, thus the model represented marginally acceptable data fit. In Model $3 \mathrm{~b}$ independent variables were allowed to correlate freely, and this model yielded good fit statistics, namely a $\chi^{2}$ of $148.65(d f=135, p=0.199)$ with $\mathrm{RMSEA}=0.025$; $\mathrm{GFI}=0.922$; $\mathrm{CFI}=0.988$. The improved fit indicates that there is shared variance between the independent variables.

The regression coefficients can be seen in Table 7 . From the five regression coefficients, four achieved significance $(p<0.05)$ : complementary capabilities $\rightarrow$ innovation breadth $(\beta=0.43, t=-0.93)$, diffusion $\rightarrow$ innovation breadth $(\beta=0.25, t=0.55)$, strategic spillovers $\rightarrow$ innovation breadth $(\beta=0.30, t=0.65)$, enhancement $\rightarrow$ innovation breadth $(\beta=0.23, t=0.44)$. While four regression coefficients are positive, complementary capabilities has a negative relationship with innovation breadth. Also, while simple correlations showed (Table 8) that all factors correlated with the dependent variables, a more subtle pattern emerged when we fitted our structural models. The latter result is not unexpected, and points to an investment in innovation capabilities that would take

Table 7 Regression coefficients (structural relationships) full structural equation models

\begin{tabular}{lll}
\hline Path & Model 3a & Model 3b \\
\hline Complementary capabilities $\rightarrow$ innovation breadth & -.40 & -.93 \\
Diffusion $\rightarrow$ innovation breadth & $(-.80)$ & $(-2.15)$ \\
& .45 & .55 \\
Strategic spillovers $\rightarrow$ innovation breadth & $(2.90)$ & $(2.20)$ \\
& .50 & .65 \\
Inter-firm co-creation $\rightarrow$ innovation breadth & $(3.36)$ & $(1.97)$ \\
Enhancement $\rightarrow$ innovation breadth & .40 & .44 \\
& $(2.68)$ & $(1.15)$ \\
\hline
\end{tabular}


Table 8 Pearson's correlations

\begin{tabular}{llllllll}
\hline Variable & Mean & SD & 1 & 2 & 3 & 4 & 5 \\
\hline 1. Complementary capabilities & 3.00 & 0.92 & 1 & & & & \\
2. Diffusion & 3.58 & 0.9 & $0.517 * * *$ & 1 & & & \\
3. Strategic spillovers & 2.88 & 1.03 & $0.554 * * *$ & $0.237 * *$ & 1 & & \\
4. Enhancement & 3.21 & 0.88 & $0.484 * * *$ & $0.394 * * *$ & $0.414 * * *$ & 1 & \\
5. Inter-firm co-creation & 3.18 & 1.03 & $0.654 * * *$ & $0.459 * * *$ & $0.498^{* * *}$ & $0.436 * * *$ & 1 \\
6. Innovation breadth & 4.52 & 1.88 & $0.256^{* * * *}$ & $0.268^{* * *}$ & $0.348^{* * *}$ & $0.312^{* * *}$ & $0.339 * * *$ \\
\hline
\end{tabular}

${ }^{*} p<0.05 ; * * p<0.01 ; * * * p<0.001$

up resources in the short-term, and take longer to lead to pay-off for the firm. Taken together, and explained below, these results confirm nomological validity.

The second dependent variable, Tobin's $Q$, was calculated based on secondary data. Since the companies in the survey were listed on the stock exchange, we were able to collect performance measurements from annual reports. We used available financial data from the last two fiscal years, namely 2016 and 2017, to calculate a Tobin's $Q$ ratio, which is used to represent a firm's market value to the replacement cost of its assets (Morck et al. 1988). This ratio is calculated as the total market value of the firm divided by the total assets value (Tobin 1969). Tobin's Q is widely used to represent shareholder's expectations of growing returns (e.g., Belderbos et al. 2010; David et al. 2010; Fang et al. 2008; Visnjic et al. 2016). A share price premium reflected in Tobin's Q suggests that the market has factored future growth potential into the current value of the company.

Using this ratio as the dependent variable and following the same procedure described for the first dependent variable, we built Model 3c (correlations set to zero) and $3 d$ (freely correlating). Model $3 c$ yielded a $\chi^{2}$ of $436.15(d f=145, p=0.000)$ with $\mathrm{RMSEA}=0.111$; GFI $=0.763$; $\mathrm{CFI}=0.749$, thus the model represented marginally acceptable data fit. Model 3d yielded good fit statistics, namely a $\chi^{2}$ of $155.01(d f=135$, $p=0.115)$ with $\mathrm{RMSEA}=0.030 ; \mathrm{GFI}=0.920 ; \mathrm{CFI}=0.983$. The regression coefficients can be seen in Table 9. From the five regression coefficients, three achieved significance $(p<0.05)$ : strategic spillovers $\rightarrow$ Tobin's Q $(\beta=0.163, t=-0.32)$, enhancement $\rightarrow$ Tobin's $\mathrm{Q}(\beta=0.13, t=-0.44)$; inter-firm co-creation $\rightarrow$ Tobin's $\mathrm{Q}(\beta=0.22$,

Table 9 Regression coefficients (structural relationships) full structural equation models

\begin{tabular}{lll}
\hline Path & Model 3c & Model 3d \\
\hline Complementary capabilities $\rightarrow$ TobinsQ & .06 & .10 \\
& $(.89)$ & $(.45)$ \\
Diffusion $\rightarrow$ TobinsQ & .08 & .06 \\
& $(1.10)$ & $(.49)$ \\
Strategic spillovers $\rightarrow$ TobinsQ & -.18 & -.32 \\
& $(-2.39)$ & $(-1.98)$ \\
Inter-firm co-creation $\rightarrow$ TobinsQ & .21 & .44 \\
& $(2.89)$ & $(2.02)$ \\
Enhancement $\rightarrow$ TobinsQ & -.34 & -.45 \\
& $(-4.37)$ & $(-3.40)$ \\
\hline
\end{tabular}


$t=0.44$ ). While three regression coefficients are positive, strategic spillovers and enhancement have a negative relationship with Tobin's Q.

\section{Discussion}

Our review of the outbound non-pecuniary innovation literature confirmed that the concept has not been addressed systematically in the OI literature, as West and Bogers (2014) suggested, but is important because firms are doing it in more or less systematic way (open source software as a case in point). Nonetheless, we were able to identify six major themes of revealing by firms: problem disclosure, capability-seeking, co-creation, enhancement, diffusion, and strategic spillovers. Exploratory and confirmatory factor analyses of data collected based on these themes, led to the identification of a five, rather than a six, factor solution.

Upon closer inspection, the first factor, complementary capabilities, represented two of the original constructs-capability-seeking and problem disclosure. From a theoretical perspective it makes sense that if firms are looking for complementary capabilities in the market they need to disclose details of innovation problems to other parties. This finding in line with Harhoff et al. (2003: 21) arguments that complementary capabilities represent an important part of 'free revealing'.

The second factor retained most of the items from diffusion. In recent years, we have observed business models based on platforms where parts of a firm innovate to disclose, for free or at cost, services or products to consumers so they can improve their value capture from their other complementary services or products. The classic examples are related with IT platforms, but more recently, the approach has also been applied to more traditional products. Home capsule coffee machines or home printers (e.g., Matzler et al. 2013) are examples of firms capturing revenues from the sale of supplies rather than from the platform where the supplies are used. This is known as the "bait and hook" business model (Teece 2010: 179), where diffusion is important to attract consumers to their platform for further rents from complementary products or services (Fichman 2004).

The third and fourth factors represented strategic spillovers and co-creation (with other firms) respectively. Strategic spillovers occur when firms attempt to create ecosystems that will facilitate exchange of tacit knowledge that will be advantageous to all. Co-creation with other firms represents the ability and willingness of firms to develop innovations with others, knowing that tacit knowledge spillovers will inevitably happen. Even in settings where the objective is a pecuniary one, when firms collaborate to co-create, it is inherent that free tacit knowledge would be outbound (Kogut 1988).

The last factor, enhancement, indicates that firms create informal collaborative arrangements to help with the development of innovations and complementary products. These collaborative arrangements are less formal than in co-creation settings and, usually, the knowledge is selective (West 2003).

Using a multi-factor model (Model 1) and a higher order factor model (Model 2) we confirmed the convergent and divergent validity of the proposed scale and verified the unidimensionality of the scale. Our structural models (Models 3a and 3b) illustrated that these factors relate to innovation breadth with four of five constructs being significant, thereby confirming predictive validity of our scale against different outcomes. These results explain the importance of complementary capabilities, diffusion, strategic spillovers and enhancement for innovation breadth. However, complementary capabilities are negatively related to 
innovation breadth whereas diffusion, strategic spillovers and enhancement are positively related. These results should not come as a surprise because firms that disclose problems and engage in capability seeking, the two factors within complementary capabilities, do so because they want to invest in specific projects. These firms are also 'playing a long game', and would expect a period of negative returns before their investments start to pay off. There is a period of time between value creation and value capture in most forms of revealing. It is therefore entirely possible that the other factors in our model could, for example, mediate the relationship between complementary capabilities and innovation breadth. Firms that are motivated by strategic spillovers and enhancement look to embrace more products/services, which influences innovation breadth more immediately. Co-creation with other firms was not significantly related to innovation breadth. An explanation might be that co-creation with other firms is usually associated with competitors or suppliers and entails a formalization that can limit the number of products or projects under development due to limitations on managerial attention (Ingham and Mothe 1998), A second structural model (Models 3c and 3d) showed that our constructs relate to firm performance in the form of shareholders' perception (Tobin's Q). These models indicate that inter-firm co-creation is a significant positive predictor and strategic spillovers and enhancement are significant but negative predictors. Together these results suggest that shareholders may understand the benefits of inter-firm collaborations to create new products (Tamer Cavusgil et al. 2003), but may be more skeptical on how strategic spillovers and enhancement can capture value for the firm over the longer term. While this highlights the importance of looking at both value creation and value capture in OI (Chesbrough et al. 2018) it also further supports the predictive validity of our scale, especially since we used a different data source.

\section{Implications}

To summarize, we first aggregated the diverse and disjointed literature on revealing in an attempt to explain how firms engage in outbound non-pecuniary OI. In doing so, we identified a number of important themes that explain revealing practices of firms. These themes formed the basis of our proposed scale for revealing, consisting of five subscales (complementary capabilities, diffusion, strategic spillovers, enhancement and inter-firm co-creation). Second, structural models confirmed that capacity building matters for innovation breadth in the sense that firms that focus on complementary capabilities are focused on a small number of projects. In contrast, the models confirmed that diffusion, strategic spillovers and enhancement are important factors for firms' innovation breadth, indicating the imperative of building an innovation ecosystem for new technologies.

The use of two conceptually different dependent variables from different data sources allowed us to consider important implications of not only our scale, but also of the concept of revealing more generally. Innovation breadth represents the ability of firms to create innovation outcomes through the various processes that they implement and the capabilities that they develop to support these processes. It therefore represents the most immediate outcome that can be expected from open innovation. Our structural model indicated that one factor (inter-firm co-creation) did not contribute significantly to innovation breadth. As this factor had a strong element of interaction with other stakeholders, and our dependent variable reflects a range of innovation types, we conclude that this type of revealing is more likely focused on product/service innovation, rather than on innovation that is more internally directed, such as process innovation (Damanpour 
et al. 2009; Piening and Salge 2015). However, the other factors either supported or detracted from innovation breadth. Diffusion, enhancement and strategic spillovers all positively related to innovation breadth. These factors all point to investment in stakeholder relationships, which we interpret as managers being supportive of an innovation ecosystem. Complementary capabilities, however, negatively relates with innovation breadth, suggesting that managers are not using revealing to focus on specific projects, but instead on a broader ecosystem. Indeed, the prominence of these four factors on innovation breadth suggests that revealing can be used as part of a broader OI strategy that encourages give-and-take with stakeholders, and which enables a firm to extend its innovation activities more broadly (Gassmann and Enkel 2004).

The second dependent variable, Tobin's Q, measures how shareholders perceive the value of the firm. Our results suggest that contrary to managers, shareholders may see the potential of using inter-firm collaborative arrangements, however they may be skeptical about the use of revealing for enhancement or strategic spillovers, indicating a lesser importance on innovative ecosystems. Diffusion and complementary capabilities were not significant constructs when related with shareholders perceived valueTobin's Q. As these factors had a strong element of knowledge transfer to other firms, without being involved in joint projects, as happens in inter-firm co-creation, shareholders might see this as a potential threat to valuable internal knowledge. At the same time, they might recognize that is a first step to establish future inter-firm co-creations, in a resembling process of the paradox of replication (Kogut and Zander 1992). In summary, using our scale highlights how managers perceive revealing and how that might differ from shareholder perspectives, which is an important future research avenue. It also confirms the capacity of our scale to capture nuances within the broader revealing construct.

From a practical managerial perspective, our main contribution relates to using our scale to measure how knowledge disclosure impacts value capture and value creation. Such analysis can assist firms in appropriately adjusting their revealing strategies to potentiate their strategies. Firms can also use our scale to understand the different dimensions of revealing and how each of them can be used differently based on the firms' objectives. Furthermore, our results show that managers are using revealing in specific ways that serve different interests. Strategic spillovers, diffusion and enhancement, for example, have been used for innovation breadth indicating that managers might be interested in building positive-sum game ecosystems within an industry. This is particularly interesting because firms are willing to reveal to get external knowledge from ecosystems but then use this knowledge in an unique manner. Complementary capabilities, in contrast, have a negative impact on a firm's innovation breadth, indicating that managers use complementary capabilities when they want to focus on a reduced number of innovation options. Because complementary capabilities are related to disclosing problems and engaging in capability seeking, we might expect to see managers investing in specific projects. Furthermore, the negative impact might relate to the long-term perspective of product development that entails a period of negative returns before investments start to pay off. Finally, our results suggest that when managers want to build a platform, thus using inter-firm co-creation, they do so without a diversity of innovation forms. However, our data suggest that the view of shareholders differs from the firms' managers. Shareholders do not appear to perceive the value of building innovation ecosystems, which is translated in the enhancement and strategic spillovers negative significant values. Instead, shareholders appear to have a positive view of the firm being able to create and capture value by developing inter-firm co-creations. 


\section{Conclusion: future research and limitations}

While OI theory has been adopted quickly over the past couple of decades, we argued in this paper that its advancement is hampered by our lack of empirical understanding of the role of non-pecuniary, outbound OI (revealing), in regards to other organizational practices and performance. Partially motivated by a lack of appropriate measures to operationalize, this paper set out to remedy this gap by developing and testing a measurement scale. Our study points to deliberate revealing as an important aspect or organizational innovation, indeed critical for the transaction of intellectual property even before 'open innovation' paradigm.

Throughout our discussion we have outlined some avenues for using our new scale. At this point we highlight four additional future research directions on the basis of our work. First, the potential to understand how revealing strategies differ among firms from different industries, or start-up versus mature firms, may address new and interesting research questions. For example, researchers have speculated that when in- and out-bound flows are coupled, they lead to improved innovation outcomes for firms (Laursen and Salter 2006). However, without the ability to measure revealing, it is unclear how this would work, and therefore unclear if the relationships are perhaps not synergistic, but perhaps a tradeoff. Because firms have limited resources and have to decide where best to apply those resources during the innovation process, it would be interesting to see if appropriation activities that protect knowledge result in fewer resources being used for revealing activities that invest in future innovation. This relationship between appropriability and revealing can be tested in outbound non-pecuniary settings using our scale to understand how appropriability will impact revealing and, in turn, how this impacts value creation and value capture.

A second avenue would be to investigate the extent to which financial rewards (incentives) may demotivate non-pecuniary contributors, or how to maximize engagement in OI contests focused on social outcomes, like clean water and sanitation in the developing world. Our scale allows researchers to investigate the relationships between other aspects of innovation and how they relate to revealing forms.

Third, our scale enables researchers to understand the conditions that lead firms to choose revealing as an important stakeholder communication strategy. This invites researchers to understand the mechanisms that underpin revealing from an organization's perspective. For example, using our scale it would be possible to understand how the different types of revealing impact value creation and value capture.

Last, the structural models suggest that managers and shareholders may have different perspectives on revealing. Future studies should focus on how revealing relates with value creation and value capture and on the understanding of how firms' manager and shareholders perceive the relationship of revealing with each of them. The study of the individuals as a unit of analysis would help to further understand this relationship. Theoretically, our data suggest that managers have a longer-term perspective and are keen to build an innovation ecosystem, whereas shareholders may have a shorter-term perspective. This is surprising since past literature have suggested the contrary (Bebchuk et al. 2015; Kay 2012). The challenge is for managers to deal with shareholder expectations while building an innovation ecosystem that allows innovation to flourish. Our scale will enable researchers to study how value is created through revealing and also how it is captured. Moreover, our scale will allow managers to empirically communicate the benefits of revealing with shareholders, thus reducing agency costs. 
Our study has several limitations. First, our study relates to listed firms, which means that we cannot generalize our results to the entire business community. Some can argue that listed firms are more open and exposed to following OI strategies. Second, our sample is not longitudinal. We recognize that some research questions may best be answered through a longitudinal design. For example, it would be interesting to observe how revealing evolves over time and how organizational capabilities and structures adapt. This is supported by Ahuja (2000), who shows that longitudinal studies are critical in the innovation field. We therefore propose that this scale with its subscales, should be part of models tested by a longitudinal research design to allow for temporal hypotheses to be tested. Third, we do not capture data from the other agents involved on our firm's ecosystem to understand the in-depth mechanisms that firms are using for revealing and how the tradeoff with pecuniary OI mechanisms happen. Finally, the primarily Australian context may have limited generalizability to other settings, which calls for replication studies elsewhere.

Acknowledgements The preparation of this paper was supported by an Australian Research Council Discovery Grant (DP160100602) on Open Innovation

Open Access This article is licensed under a Creative Commons Attribution 4.0 International License, which permits use, sharing, adaptation, distribution and reproduction in any medium or format, as long as you give appropriate credit to the original author(s) and the source, provide a link to the Creative Commons licence, and indicate if changes were made. The images or other third party material in this article are included in the article's Creative Commons licence, unless indicated otherwise in a credit line to the material. If material is not included in the article's Creative Commons licence and your intended use is not permitted by statutory regulation or exceeds the permitted use, you will need to obtain permission directly from the copyright holder. To view a copy of this licence, visit http://creativecommons.org/licenses/by/4.0/.

\section{References}

Afuah, A., \& Tucci, C. L. (2012). Crowdsourcing as a solution to distant search. Academy of Management Review, 37(3), 355-375.

Ahuja, G. (2000). Collaboration networks, structural holes, and innovation: A longitudinal study. Administrative Science Quarterly, 45(3), 425-455.

Alexy, O. (2009). Free revealing: How firms can profit from being open. Berlin: Springer.

Alexy, O., Bascavusoglu-Moreau, E., \& Salter, A. J. (2016). Toward an aspiration-level theory of open innovation. Industrial and Corporate Change, 25(2), 289-306.

Alexy, O., George, G., \& Salter, A. J. (2013). Cui bono? The selective revealing of knowledge and its implications for innovative activity. Academy of Management Review, 38(2), 270-291.

Alexy, O., \& Reitzig, M. (2013). Private-collective innovation, competition, and firms' counterintuitive appropriation strategies. Research Policy, 42(4), 895-913.

Anderson, E., \& Weitz, B. (1992). The use of pledges to build and sustain commitment in distribution channels. Journal of Marketing Research, 29(1), 18-34.

Anderson, J. C., \& Gerbing, D. W. (1988). Structural equation modeling in practice: A review and recommended two-step approach. Psychological Bulletin, 103(3), 411.

Bagozzi, R. P., Yi, Y., \& Phillips, L. W. (1991). Assessing construct validity in organizational research. Administrative Science Quarterly, 36(3), 421-458.

Bakker, R. M. (2010). Taking stock of temporary organizational forms: A systematic review and research agenda. International Journal of Management Reviews, 12(4), 466-486.

Baldwin, C., \& Von Hippel, E. (2011). Modeling a paradigm shift: From producer innovation to user and open collaborative innovation. Organization Science, 22(6), 1399-1417.

Barney, J. (1991). Firm resources and sustained competitive advantage. Journal of Management, 17(1), 99-120.

Baruch, Y. (1999). Response rate in academic studies: A comparative analysis. Human Relations, 52(4), 421-438.

Bebchuk, L. A., Brav, A., \& Jiang, W. (2015). The long-term effects of hedge fund activism. Cambridge: National Bureau of Economic Research. 
Belderbos, R., Faems, D., Leten, B., \& Looy, B. V. (2010). Technological activities and their impact on the financial performance of the firm: Exploitation and exploration within and between firms. Journal of Product Innovation Management, 27(6), 869-882.

Bogers, M., Zobel, A.-K., Afuah, A., Almirall, E., Brunswicker, S., Dahlander, L., et al. (2017). The open innovation research landscape: Established perspectives and emerging themes across different levels of analysis. Industry and Innovation, 24(1), 8-40.

Cammarano, A., Michelino, F., Lamberti, E., \& Caputo, M. (2017). Accumulated stock of knowledge and current search practices: The impact on patent quality. Technological Forecasting and Social Change, 120, 204-222. https://doi.org/10.1016/j.techfore.2016.12.019.

Cattell, R. B. (1966). The scree test for the number of factors. Multivariate Behavioral Research, 1(2), $245-276$.

Chesbrough, H. (2006). The era of open innovation. Managing Innovation and Change, 127(3), 34-41.

Chesbrough, H. (2012). Open innovation: Where we've been and where we're going. Research-Technology Management, 55(4), 20-27.

Chesbrough, H., \& Crowther, A. K. (2006). Beyond high tech: Early adopters of open innovation in other industries. $R \& D$ Management, 36(3), 229-236.

Chesbrough, H., Lettl, C., \& Ritter, T. (2018). Value capture in open innovation systems: Value at the interface. Journal of Product Innovation Management, 35(6), 1-9.

Chesbrough, H., Vanhaverbeke, W., \& West, J. (2014). New frontiers in open innovation. Oxford: Oxford University Press.

Choi, N., \& Yi, K. (2015). Raising the general public's awareness and adoption of open source software through social Q\&A interactions. Online Information Review, 39(1), 119-139.

Churchill, G. A. (1979). A paradigm for developing better measures of marketing constructs. Journal of Marketing Research, 16(1), 64-73.

Cohen, W. M., \& Levinthal, D. A. (1990). Absorptive capacity: A new perspective on learning and innovation. Administrative Science Quarterly, 35(1), 128-152.

Dahlander, L., \& Gann, D. M. (2010). How open is innovation? Research Policy, 39(6), 699-709.

Dahlander, L., \& Magnusson, M. (2008). How do firms make use of open source communities? Long Range Planning, 41(6), 629-649.

Damanpour, F., Walker, R. M., \& Avellaneda, C. N. (2009). Combinative effects of innovation types and organizational performance: A longitudinal study of service organizations. Journal of Management Studies, 46(4), 650-675.

David, P., O'Brien, J. P., Yoshikawa, T., \& Delios, A. (2010). Do shareholders or stakeholders appropriate the rents from corporate diversification? The influence of ownership structure. Academy of Management Journal, 53(3), 636-654.

DeVellis, R. F. (2016). Scale development: Theory and applications. Thousand Oaks: Sage Publications.

Dhanaraj, C., \& Parkhe, A. (2006). Orchestrating innovation networks. Academy of Management Review, 31(3), 659-669.

Dodgson, M. (1994). Technological collaboration and innovation. In The handbook of industrial innovation (pp. 285-292).

Dodgson, M., Gann, D., \& Salter, A. (2006). The role of technology in the shift towards open innovation: The case of Procter and Gamble. R\&D Management, 36(3), 333-346.

Dodgson, M., Gann, D. M., \& Salter, A. (2007). "In case of fire, please use the elevator": Simulation technology and organization in fire engineering. Organization Science, 18(5), 849-864.

Dodgson, M., Hughes, A., Foster, J., \& Metcalfe, S. (2011). Systems thinking, market failure, and the development of innovation policy: The case of Australia. Research Policy, 40(9), 1145-1156.

Fang, E., Palmatier, R. W., \& Steenkamp, J.-B. E. (2008). Effect of service transition strategies on firm value. Journal of Marketing, 72(5), 1-14.

Fichman, R. G. (2004). Real options and IT platform adoption: Implications for theory and practice. Information Systems Research, 15(2), 132-154.

Garriga, H., Von Krogh, G., \& Spaeth, S. (2013). How constraints and knowledge impact open innovation. Strategic Management Journal, 34(9), 1134-1144.

Gassmann, O., \& Enkel, E. (2004). Towards a theory of open innovation: Three core process archetypes. In Research platform Alexandria.

Gault, F., \& von Hippel, E. A. (2009). The prevalence of user innovation and free innovation transfers: Implications for statistical indicators and innovation policy. In SSRN.

Gerbing, D. W., \& Anderson, J. C. (1988). An updated paradigm for scale development incorporating unidimensionality and its assessment. Journal of Marketing Research, 25(2), 186-192.

Hair, J. F., Black, W. C., Babin, B. J., Anderson, R. E., \& Tatham, R. L. (1998). Multivariate data analysis. Upper Saddle River, NJ: Prentice Hall. 
Hakanen, T. (2014). Co-creating integrated solutions within business networks: The KAM team as knowledge integrator. Industrial Marketing Management, 43(7), 1195-1203.

Hambrick, D. C., \& Mason, P. A. (1984). Upper echelons: The organization as a reflection of its top managers. Academy of Management Review, 9(2), 193-206.

Hamel, G. (1991). Competition for competence and interpartner learning within international strategic alliances. Strategic Management Journal, 12(S1), 83-103.

Harhoff, D. (1996). Strategic spillovers and incentives for research and development. Management Science, 42(6), 907-925.

Harhoff, D., Henkel, J., \& Von Hippel, E. (2003). Profiting from voluntary information spillovers: How users benefit by freely revealing their innovations. Research Policy, 32(10), 1753-1769.

Henkel, J. (2006). Selective revealing in open innovation processes: The case of embedded Linux. Research Policy, 35(7), 953-969.

Henkel, J., \& Baldwin, C. Y. (2010). Modularity for value appropriation-how to draw the boundaries of intellectual property. In SSRN.

Henkel, J., Schöberl, S., \& Alexy, O. (2014). The emergence of openness: How and why firms adopt selective revealing in open innovation. Research Policy, 43(5), 879-890.

Huizingh, E. K. (2011). Open innovation: State of the art and future perspectives. Technovation, 31(1), 2-9.

Ingham, M., \& Mothe, C. (1998). How to learn in R\&D partnerships? R\&D Management, 28(4), $249-261$.

Jeppesen, L. B., \& Lakhani, K. R. (2010). Marginality and problem-solving effectiveness in broadcast search. Organization Science, 21(5), 1016-1033.

Jöreskog, K. G., \& Sörbom, D. (1996). LISREL 8: User's reference guide. Lincolnwood: Scientific Software International.

Kale, P., Singh, H., \& Perlmutter, H. (2000). Learning and protection of proprietary assets in strategic alliances: Building relational capital. Strategic Management Journal, 21(3), 217-237.

Kay, J. (2012). The Kay review of UK equity markets and long-term decision making. Final Report, 112.

Kogut, B. (1988). Joint ventures: Theoretical and empirical perspectives. Strategic Management Journal, 9(4), 319-332.

Kogut, B., \& Zander, U. (1992). Knowledge of the firm, combinative capabilities, and the replication of technology. Organization Science, 3(3), 383-397.

Lamberti, E., Michelino, F., Cammarano, A., \& Caputo, M. (2017). Open innovation scorecard: A managerial tool. Business Process Management Journal, 23(6), 1126-1244.

Laursen, K., \& Salter, A. (2006). Open for innovation: The role of openness in explaining innovation performance among UK manufacturing firms. Strategic Management Journal, 27(2), 131-150.

Laursen, K., \& Salter, A. J. (2014). The paradox of openness: Appropriability, external search and collaboration. Research Policy, 43(5), 867-878.

Leiponen, A., \& Helfat, C. E. (2010). Innovation objectives, knowledge sources, and the benefits of breadth. Strategic Management Journal, 31(2), 224-236.

Lopez-Vega, H., Tell, F., \& Vanhaverbeke, W. (2016). Where and how to search? Search paths in open innovation. Research Policy, 45(1), 125-136.

Love, J. H., Roper, S., \& Du, J. (2009). Innovation, ownership and profitability. International Journal of Industrial Organization, 27(3), 424-434.

Macdonald, S. (1993). Nothing either good or bad: Industrial espionage and technology transfer. International Journal of Technology Management, 8(1-2), 95-105.

Machlup, F., \& Penrose, E. (1950). The patent controversy in the nineteenth century. The Journal of Economic History, 10(1), 1-29.

Matzler, K., Bailom, F., Friedrich von den Eichen, S., \& Kohler, T. (2013). Business model innovation: Coffee triumphs for Nespresso. Journal of Business Strategy, 34(2), 30-37.

Michelino, F., Cammarano, A., Lamberti, E., \& Caputo, M. (2015). Knowledge domains, technological strategies and open innovation. Journal of Technological Management \& Innovation, 10(2), 50-78.

Michelino, F., Caputo, M., Cammarano, A., \& Lamberti, E. (2014). Inbound and outbound open innovation: Organization and performance. Journal of Technological Management \& Innovation, 9(3), 65-82.

Morck, R., Shleifer, A., \& Vishny, R. W. (1988). Management ownership and market valuation: An empirical analysis. Journal of Financial Economics, 20, 293-315.

Mowery, D. C., Oxley, J. E., \& Silverman, B. S. (1996). Strategic alliances and interfirm knowledge transfer. Strategic Management Journal, 17(S2), 77-91.

Newbert, S. L. (2007). Empirical research on the resource-based view of the firm: An assessment and suggestions for future research. Strategic Management Journal, 28(2), 121-146.

Nickerson, J. A., \& Zenger, T. R. (2004). A knowledge-based theory of the firm-the problem-solving perspective. Organization Science, 15(6), 617-632. 
Parent, M., Gallupe, R. B., Salisbury, W. D., \& Handelman, J. M. (2000). Knowledge creation in focus groups: Can group technologies help? Information \& Management, 38(1), 47-58.

Peres, R., Muller, E., \& Mahajan, V. (2010). Innovation diffusion and new product growth models: A critical review and research directions. International Journal of Research in Marketing, 27(2), 91-106.

Piening, E. P., \& Salge, T. O. (2015). Understanding the antecedents, contingencies, and performance implications of process innovation: A dynamic capabilities perspective. Journal of Product Innovation Management, 32(1), 80-97.

Piezunka, H., \& Dahlander, L. (2015). Distant search, narrow attention: How crowding alters organizations' filtering of suggestions in crowdsourcing. Academy of Management Journal, 58(3), 856-880.

Ries, E. (2011). The lean startup: How today's entrepreneurs use continuous innovation to create radically successful businesses. New York: Crown Books.

Ries, E. (2017). The startup way: How modern companies use entrepreneurial management to transform culture and drive long-term growth. Currency.

Rindfleisch, A., Malter, A. J., Ganesan, S., \& Moorman, C. (2008). Cross-sectional versus longitudinal survey research: Concepts, findings, and guidelines. Journal of Marketing Research, 45(3), 261-279.

Ritala, P., Olander, H., Michailova, S., \& Husted, K. (2015). Knowledge sharing, knowledge leaking and relative innovation performance: An empirical study. Technovation, 35, 22-31.

Rogers, E. M. (2010). Diffusion of innovations. New York: Simon and Schuster.

Schreiber, J. B., Nora, A., Stage, F. K., Barlow, E. A., \& King, J. (2006). Reporting structural equation modeling and confirmatory factor analysis results: A review. The Journal of Educational Research, 99(6), 323-338.

Schumpeter, J. A. (1934). The theory of economic development: An inquiry into profits, capital, credit, interest, and the business cycle. Redvers Opie, Cambridge, MA: Harvard University Press.

Shah, S. K. (2006). Motivation, governance, and the viability of hybrid forms in open source software development. Management Science, 52(7), 1000-1014.

Steen, J., Hanson, D., \& Liesch, P. (1998). Collaborative research and development: New insights from cyclic models of the innovation process. International Journal of Innovation Management, 2(01), $107-121$.

Stratman, J. K., \& Roth, A. V. (2002). Enterprise resource planning (ERP) competence constructs: Twostage multi-item scale development and validation. Decision Sciences, 33(4), 601-628.

Tamer Cavusgil, S., Calantone, R. J., \& Zhao, Y. (2003). Tacit knowledge transfer and firm innovation capability. Journal of Business \& Industrial Marketing, 18(1), 6-21.

Teece, D. J. (1986). Profiting from technological innovation: Implications for integration, collaboration, licensing and public policy. Research Policy, 15(6), 285-305.

Teece, D. J. (1988). Capturing value from technological innovation: Integration, strategic partnering, and licensing decisions. Interfaces, 18(3), 46-61.

Teece, D. J. (2010). Business models, business strategy and innovation. Long Range Planning, 43(2), $172-194$.

Tietze, F. (2017). How an open approach to patents could help build a sustainable future. In The Conversation.

Tobin, J. (1969). A general equilibrium approach to monetary theory. Journal of Money, Credit and Banking, 1(1), 15-29.

Tranfield, D., Denyer, D., \& Smart, P. (2003). Towards a methodology for developing evidence-informed management knowledge by means of systematic review. British Journal of Management, 14(3), 207-222.

Vandermerwe, S., \& Rada, J. (1988). Servitization of business: Adding value by adding services. European Management Journal, 6(4), 314-324.

Vanhaverbeke, W. (2006). The interorganizational context of open innovation. In Open innovation: Researching a new paradigm (pp. 205-219).

Verreynne, M. L., Meyer, D., \& Liesch, P. (2016). Beyond the formal-informal dichotomy of small firm strategy-making in stable and dynamic environments. Journal of Small Business Management, 54(2), 420-444.

Visnjic, I., Wiengarten, F., \& Neely, A. (2016). Only the brave: Product innovation, service business model innovation, and their impact on performance. Journal of Product Innovation Management, 33(1), 36-52.

Von Hippel, E. (1986). Lead users: A source of novel product concepts. Management Science, 32(7), 791-805.

von Hippel, E. (1988). The sources of innovation (1st ed.). New York: Oxford University Press. 221 pp. 
von Hippel, E., DeMonaco, H., \& de Jong, J. P. (2017). Market failure in the diffusion of clinician-developed innovations: The case of off-label drug discoveries. Science and Public Policy, 44(1), 121-131.

West, J. (2003). How open is open enough?: Melding proprietary and open source platform strategies. Research Policy, 32(7), 1259-1285.

West, J. (2006). Does appropriability enable or retard open innovation. In Open innovation: Researching a new paradigm (pp. 109-133).

West, J., \& Bogers, M. (2014). Leveraging external sources of innovation: A review of research on open innovation. Journal of Product Innovation Management, 31(4), 814-831.

West, J., \& Bogers, M. (2017). Open innovation: Current status and research opportunities. Innovation, $19(1), 43-50$.

West, J., \& Gallagher, S. (2006). Challenges of open innovation: The paradox of firm investment in opensource software. R\&D Management, 36(3), 319-331.

West, J., \& Lakhani, K. R. (2008). Getting clear about communities in open innovation. Industry and Innovation, 15(2), 223-231.

West, J., Salter, A., Vanhaverbeke, W., \& Chesbrough, H. (2014). Open innovation: The next decade. Amsterdam: Elsevier.

Yoo, B., \& Donthu, N. (2001). Developing and validating a multidimensional consumer-based brand equity scale. Journal of Business Research, 52(1), 1-14.

Zaichkowsky, J. L. (1985). Measuring the involvement construct. Journal of Consumer Research, 12(3), 341-352. 